\title{
Introduction*
}

This article relies on quantitative data to survey penal, punitive and coercive $\mathrm{e}^{\mathrm{i}}$ industrial legislation passed by the Australian Federal Government from 1901 to 2020. It demonstrates empirically that until recently, coercive legislation has been relatively uncommon in federal Australian labour law. Labour disputation in Australia has traditionally been the province of conciliation and arbitration: bargaining between strong trade unions and capital, with the state used by both parties to structure and secure their legal relationship and the terms of their negotiations. Since the 1970s, however, coercive labour law, together with particular cultural and structural economic changes (such as engineered unemployment (Mitchell and Fazi, 2017: 122, 238)), have played a hand in neutering a national trade union movement. This increase in coercive labour law has also contributed to the decline of a robust civil system of arbitration and conciliation in which unions acted as the fulcrum. A system of punitive regulation has grown-up in its place, forming a new model of employment relations in which courts, rather than tribunals, hold unprecedented power over individual workers and organised labour. Capital, by contrast, has been affected by this shift to a far lesser extent. Intricate and labyrinthine systems of penal sanctions, fines as well as union deregistration are woven throughout the fabric of the dominant federal statutes and legislation governing the Australian law of work.

This is a trend that has not gone unnoticed in the field of industrial relations scholarship over the past two decades (Cooper and Ellem, 2017; 2013: 168-9; 2008: 541; Dabscheck, 2001; Forsyth and Stewart, 2017; Peetz, 1998) as well as over the past three years of legislative observation in this journal (Rawling and Schofield-Georgeson, 2017; 2018; 2019). However, 
it is not until now that the coercive and punitive aspects of such laws have been historically compared and measured. And it is only by placing such laws in historical context, particularly alongside those enacted against trade unions in the past, that the scale and quality of this systemic change can truly be understood.

The substance of the recent trend toward coercive provisions in labour law purports to police aspects of the employment relationship once the province of bargaining and negotiation between labour and capital. Other such provisions single-out organised labour for prosecution, with little reciprocal regulation of capital. Far from 'cuts to red tape' or deregulation, the recent neoliberal age of labour relations has been characterised by intense 're-regulation' (Cooper and Ellem, 2008: 532) of labour law - a form of 'class struggle from above' (Smith, 2015: 345) directed against labour in the interests of capital. At present, a great irony of this neoliberal regulatory experiment has seen Australian Governments - some on the hard right of Australian politics -required to pass laws criminalising employers who fail to 'self-regulate' in the absence of trade union or state enforcement. 'Wage theft' laws, industrial manslaughter, criminal sanctions for the gross exploitation of 'vulnerable workers' are topical exemplars, while the revival of slavery as an industrial phenomenon has created a further hot-bed of legislative activity against employers. Growing in scale as these laws are, they nevertheless remain small in number compared to coercive laws enacted against labour.

Mapped in this article is the number of penal and coercive provisions in the field of labour law enacted by consecutive Australian federal governments over the course of the past 120 years, since the Federation of the Australian Commonwealth (from 1901 to 2020). This data has been analysed in two ways: first, by showing the trajectory or volume of federal penal or 
coercive provisions enacted and repealed over time by each federal government; and second, by recording the number of federal penal or coercive provisions enacted against either labour, capital or both over time. Over time, the data demonstrates empirically a shift from collective and mostly civil industrial relations, towards a more individualised and punitive industrial arena - an arena defined by fines and 'civil penalties'. By charting this regulatory change, it is argued here that this shift has contributed to undemocratic results, eroding the relative parity between labour and capital afforded by the previous system of industrial relations disciplining labour in the process - while enhancing the unilateral managerial power of employers. It is noted that other contributing factors to this process have included the lopsided and patchy enforcement of coercive labour law, together with broader structural economic change. Nevertheless, the paper concludes that embedded within the previous, noncoercive industrial model, are the seeds of change required to revitalise the present system in the form of what US sociologists, Joel Rogers and Joshua Cohen, have labelled, 'associative democracy' (1995: 44) (a term defined and discussed in more detail in the 'analysis' section of this paper).

The methods used to compile and categorise this data are explained in the section that follows, along with definitions of key terms. Analysis commences in the section subsequent to this. It relies on two key graphs (Figures $A$ and $B$ ) to chart first, the number of coercive labour laws passed since 1901; and second, those enacted against either labour, capital or both. The graphs are analysed chronologically, explaining the significance of coercive legislation passed by each successive Australian Federal Government. Owing to the technical complexity of the data, its discussion and relevance to contemporary labour law is treated separately and is addressed in the final section of the paper. 
Before progressing any further into this paper, it is crucial to define the terms, 'coercive' and 'punitive' labour laws which are the corpus of this study. 'Coercive' and/or 'punitive' labour laws mean singular statutory provisions which either: (i) have a criminal or pecuniary penalty attached (i.e. that are penal provisions); or (ii) have a 'civil penalty' or 'civil remedy' attached; or (iii) result in deregistration of a registered organisation, member or official (most frequently, trade unions, their members or officials). A typical example of a coercive provision is s500 of the Fair Work Act which provides that when a union official enters a workplace for one of the purposes outlined under the Act (Part 3-4) that:

A permit holder exercising, or seeking to exercise, rights in accordance with this Part must not intentionally hinder or obstruct any person, or otherwise act in an improper manner.

Note: $\quad$ This section is a civil remedy provision (see Part 4-1). General penalty provisions under s539(2) and s546 (Part 4-1) of the Act, in turn, provide that the maximum penalty for breach of a civil remedy provision is 60 Penalty Units or $\$ 13,320$ for individuals and 350 Penalty Units or $\$ 77,700$ for corporations. Less commonly, however, particular penalty provisions under the Act provide for penalties that are either half or ten times this amount. General administrative and procedural provisions such as these were not counted for the purposes of this research, which focussed exclusively on substantive coercive provisions. ${ }^{\text {ii }}$ The legal definition of a 'civil penalty' is explained in more detail below (pp. 89).

Meanwhile, the last type of sanction described above - deregistration - has been labelled 'coercive' where it terminates a trade union's ability to represent its members in an industrial 
forum, effectively spelling the 'civil death' of an organisation (Harley, 2004: 344). Taken together, deregistration and civil penalty provisions are neither strictly 'criminal', nor entirely 'civil'. Nevertheless, they must certainly be considered 'coercive and punitive'. It is this description, 'coercive and punitive' therefore, that is deployed here to describe labour laws that impose sanctions against parties in an industrial jurisdiction or forum. Such measures have sometimes been described as 'command and control' regulation: governmental standards or rules, backed by sanctions, requiring specified behaviour to prevent social harm (Baldwin, 1997: 65). In regulation discourse, these rules are often contrasted with theories of ‘responsive regulation' (Ayres and Braithwaite, 1992: 101-132), and more recently, 'really responsive regulation' (Black and Baldwin, 2008) which, in the context of Australian labour law, denote a form of 'enforced self-regulation' whereby 'social actors, including stakeholders such as trade unions, devise their own standards and implementation methods subject to public oversight and frequently, mandatory criteria (Cooney, Howe and Murray, 2006: 224; Ayres and Braithwaite, 1992: 101-132).

Understanding coercive labour legislation both historically and schematically is a tried and tested method of inquiry in the fields of industrial relations and labour law. In 1981, Merritt's comprehensive study of Australian Master and Servant Acts provided a definitive statistical analysis of prosecutions under this colonial and state legislation between 1845 and 1930. In 1989, Mitchell and Macintyre published an edited collection on the origins of the federal Australian Conciliation and Arbitration Act 1904 in which Quinlan explained the distinctive importance of coercive and 'state-interventionist' legislation to the establishment of Australian labour law at the turn of the $20^{\text {th }}$ century (1989: 25-49). As Quinlan put it, Australian industrial legislation emerged at a time when 'statutes were used in the Australian 
colonies as an almost complete substitute for common law proceedings (but) whatever its origins, the reliance on statute law is a long-term feature of the legal regulation of labour in Australia' (1989: 36). Quinlan's analysis foregrounded an extensive empirical schema in which Mitchell explained the origins and differences between various state and federal Conciliation and Arbitration Acts (1989: 74-103). In 1993, Canadian labour scholar, Roy Adams, deployed historical graphs periodising trends in regulation of trade unions across liberal democratic nation states (Adams, 1993), later referenced in an Australian context by Adams and Markey (1997: 285-288). In this respect, Adams and Markey (1997), as well as Peetz (2015) explained the significance of legislation to shaping national ideology and public attitudes towards unions: the driving force influencing union growth and membership. The sum of this scholarship demonstrates the efficacy of empirical and historical methods in studying legislation as well as the importance of legislative analysis to understanding broad patterns of social change or rather, shifts in social relations between the State, labour and capital.

Two significant issues for coercive Australian labour law that are mostly beyond the scope of this paper include: enforcement of such laws; and equivalent state and territory legislation. Both are substantial issues in their own right, without which any discussion of coercive federal labour law would be incomplete. It is for this reason that their discussion here is cursory. In relation to enforcement, Clibborn has recently argued (2020: 334) (in the wake of literally thousands of regulatory studies on the issue) that 'tough' penal legislation targeting employers in respect to offences such as 'wage theft' or worker underpayment, does not increase compliance without well-resourced and dedicated regulatory enforcement. And, as Hardy and Howe have argued, historically, Australian industrial inspectorates have been 'relatively small, significantly under-resourced and ...largely ineffectual' (2009: 315). 
Rather, 'responsive regulation' was done outside an official state regulator, conducted between trade unions and employers in industrial tribunals (Cooney, Howe and Murray, 2006: 215, 223-224). The work of Richard Mitchell in the late 1970s traced the first such shift in Australian industrial relations under the conservative Fraser Government (1979), describing it in terms of 'industrial enforcement' (1979: 435) and labelling it 'a political defeat for the trade union movement' (1980: 348).

Following neoliberal pressure to deregulate and decentralise the conciliation and arbitration system in the 1980s and 1990s, the 2005 Work Choices regulation led commentators, Cooney, Howe and Murray (2006), to view it as 'command and control' enforcement (215, 223). Since 2009, annual funding to the Federal labour inspectorate, the Fair Work Ombudsman, has doubled (p. 81). Nevertheless, a recent review of- its operations has demonstrated mixed results (Howe, Hardy and Cooney, 2012). Indeed, while its investigations have reduced non-compliance among target employer businesses (by 90\% (p.122)), less than one per cent of employers are investigated annually (p. 141). The deterrent effect of the regulator upon the remaining 99 per cent of employers remains unclear and unknown (p. 140; Maconachie and Goodwin, 2011). Other problems with its efficacy include a broad mandate (Howe, Hardy and Cooney, 2012: 86), together with a split in funding (around a quarter of regulatory labour enforcement funding is devoted to policing various parts of the labour movement through the Registered Organisations Commission and Australian Building and Construction Commission - rather than employers (FWO Annual Report, 2018-19: 59-60; ABCC Annual Report, 2018-19: 58)). When compared with the reach of an older and broader system of industry enforcement premised upon bargaining between trade unions and employers within industrial tribunals, the present system of 
coercive regulatory enforcement appears woefully inadequate, able to achieve a mere fraction of the results (discussed further below, pp. 34-39).

In respect to the issue of state and territory labour legislation, it is conceded that without these laws, the view of the Australian industrial legal landscape depicted by this study is partially obscured. As Merritt has shown, colonial penal employment law such as the Master and Servant Acts persisted in the states until well into $20^{\text {th }}$ Century (although they were seldom used, if at all during this period (1981: 182-296)). Similarly, an exclusive portrayal of federal legislation neglects penalties that existed under state and territory industrial legislation. Until the landmark constitutional ruling of the High Court in the 'Work Choices Case' (New South Wales v Commonwealth (2006) HCA 52; 229 CLR 1) when core federal labour jurisdiction prevailed over state jurisdiction, most state legislation, particularly the key industrial codes, co-existed with federal legislation. ${ }^{\text {iii }}$ And, despite Work Choices - or perhaps because of the primacy that it has afforded to a narrow range of issues covered by Federal labour regulation over the past decade - state industrial legislation is currently undergoing a revival, covering issues such as wage theft, modern slavery, labour hire licensing and industrial manslaughter. Nevertheless, it is important to note that from 1919 onwards, $80 \%$ of union members belonged to national trade unions, mostly subject to the federal system of industrial regulation (Adams and Markey, 1997: 297), as opposed to the key industrial codes of the states and territories. Qualifications aside, coercive state and territory labour laws are ripe for further scholarship and analysis.

\section{Terms and Methods}


A central aim of this project was to measure and contextualise the number of coercive and punitive labour laws passed and repealed by respective Australian Federal Governments since Federation (see Figure A, below). In this respect, Figure A represents the total of all coercive labour legislation or statutory provisions, passed and repealed since 1901. Collating this data involved reading all federal industrial legislation, categorising and tallying the number of penalty provisions passed and repealed, before classifying and visualising the data in accordance with standard research methods in the social sciences (see, for instance, Bryman, 2016: 285-307). In total, the author surveyed 1,746 coercive provisions from a total of 178 statutes. A second and further measurement compared the number 'coercive and punitive labour laws passed against labour', with those 'passed against capital' by respective Australian Federal Governments since Federation (see Figure B, below). This measure counted only legislation passed by each consecutive government, excluding repealed legislation. Put differently, Figure B represents only new legislation passed by each government.

In mapping the volume and trajectory of federal coercive or penal labour law over the past 120 years, it is first necessary to acknowledge that the definition of 'penal provisions' has been a vexed issue in Australian industrial law (see, for instance, the High Court's decision in Commonwealth of Australia v Director, Fair Work Building Industry Inspectorate; Construction, Forestry, Mining and Energy Union v Director, Fair Work Building Industry Inspectorate [2015] HCA 46 (9 December 2015)). Throughout most of the $20^{\text {th }}$ century, courts treated pecuniary penalties under employment statutes as penal in nature - albeit that offences were mostly determined summarily and frequently treated as strict liability offences (dispensing with the 'intention' or 'knowledge' element of the offence, usually in return for a more lenient penalty or fine) (Bennett, 1994: 78-79). Such a practice accorded with the legal 
treatment of other types of regulatory crime, such as corporate offending under the various Factory Acts since the mid-nineteenth century (Tombs and Whyte, 2007: 114-115).

In 1979, however, a Full Bench of the Federal Court decided that such offences were civil in nature, lowering the standard of proof for offences (or more correctly 'breaches') to the civil standard ('balance of probabilities'), rather than the criminal standard ('beyond reasonable doubt')(Gapes v Commercial Bank of Australia Ltd [1980] FCA 26). 'Civil penalties' were eventually codified in 1996 by the Howard Coalition Government's Workplace Relations Act 1996 (Cth)(s729), with the Act expressly providing that such breaches were 'not offences' (ss533(1), 170CO, 170NF, 285F, 298X). The Howard Government's 2005 Work Choices legislation further introduced the notion of 'civil remedy' provisions under which private parties prosecuting breaches of the Act could claim any penalty against the defendant for themselves. Codification of 'civil penalty' and 'civil remedy' provisions was continued by the Gillard Labour Government under its Fair Work Act 2009 (Cth) as well as by successive Coalition Governments. Despite their classification as 'civil', in 2015 the High Court commented that civil penalties and remedies in labour law shared key aspects of criminal offences, including that they coerced a defendant toward 'specific and general deterrence' in order to uphold a 'public interest in compliance' (Commonwealth v Director, FWBII (2015) French, Kiefel, Bell, Nettle, Gordon JJ at [55]). Other procedural similarities, such as plea and breach bargaining between prosecutors and defendants, led the High Court, together with commentators such as Stewart et al to speak of 'a general blurring of the traditional distinction between criminal and civil liability' (Stewart et al, 2016: 619; Commonwealth v Director, FWBII (2015) French, Kiefel, Bell, Nettle, Gordon JJ at [16]-[24], [51]-[55]). 
In comparing 'laws passed against capital' with those 'passed against labour', the term 'labour' includes: trade unions, individual workers, 'servants' and those responsible for the direct performance of work. The term 'capital' describes: shareholders, companies and their representatives, in the form of employers, 'masters' and managers or those responsible for directing how work is to be performed. Clearly there are anomalous circumstances in which particular or obscure employment relations fall outside of the common a 'labour / capital' typology as it is commonly and historically understood, i.e. health and safety or discrimination regulations applicable to contracts for services (e.g. householders who hire contractors). And in some of these instances, laws that genuinely apply to both labour and capital have been grouped under a third and independent category: 'coercive laws against both labour and capital'. Despite its imperfections, however, the 'labour /capital' typology nevertheless captures the vast majority of work and industrial arrangements around which Australian labour, industrial and employment law has been built over the past 120 years (Riley, Owens and Murray, 2011: 21-27).

It must further be explained that the classification of 'laws against labour' in this study includes penal and coercive laws related to 'registered organisations' as well as laws against 'industrial action'. This is despite the fact that the terms, 'registered organisations' and 'industrial action', are expressions of formal equality, capturing both labour unions and employer associations. In practice, however, three-quarters of the membership of registered organisations belong to trade unions (Gilfillan and McGann, 2018; ROC Annual Report, 2019: 29$)^{\mathrm{iv}}$ and in 2018-2019, 80\% of registered organisations prosecutions were against trade unions (ROC Annual Report, 2019: 40). Similarly, employer industrial action, such as 
lockouts, have been extremely rare over the course of the $20^{\text {th }}$ century (Stewart et al, 2016: 920) and the overwhelming volume of industrial action has involved strikes, undertaken by workers and trade unions. As Cooper et al show, even where there was a ten-fold increase in the amount of employer industrial action or lockouts in the aftermath of the Workplace Relations Act between 1999-2000, employer industrial action still only accounted for $2 \%$ of all industrial action - otherwise it conventionally accounts for around $0.3 \%$ of industrial action (2009: 345). Accordingly, just as this study has deployed the categories, 'labour' and 'capital' in place of legal terms such as 'employees' and 'employers' (terms that decontextualise a power imbalance inherent within the employment relationship (Collins, 2010: 6)), it further dispenses with the false neutrality embedded in the legal terms, 'registered organisations' and 'industrial action'. Doing so affords a clearer analysis of the emergence of coercive labour law and its subjects, as an ongoing historical process in the realm of industrial relations. By investigating the social outcomes of law, rather than its technocratic or literal meaning, a clearer, more representative depiction of 'laws against labour' and 'capital' is formed, affording an insight into the legitimacy of and regulatory imperatives of the rule of law in the industrial space (Lacey, 2013: 354).

Subordinate legislation such as Parliamentary regulations (as opposed to substantive Acts of Parliament) and executive rules, were mostly disregarded - unless the rule was important to a significant dispute arising over the course of the period. In this respect, the issue of 'bans clauses' from 1936 until 1983 were difficult to classify. Bans clauses were an invention by the High Court in 1936 that allowed the Conciliation and Arbitration Tribunal to insert penal clauses, enforceable by a court, into industrial awards. In effect, bans clauses permitted an executive agency to create coercive and penal rules banning industrial action. Accordingly, the legislative power to enact bans clauses has been classified as a coercive law under the 
Conciliation and Arbitration Act but particular bans clauses made under specific awards have not been counted.

\section{Analysis: Coercive labour laws, 1901 - 2020}

This section of the paper analyses the surveyed data showing that, over time, Australian labour legislation has become more coercive, transitioning from a relatively collective and civil system of conciliation and arbitration to one that is more individualised and punitive, mostly favouring capital while actively persecuting organised labour. The histogram below (Figure A) plots the trajectory, number and comparative volume of federal penal or coercive provisions in the realm of labour law, enacted and repealed over time by each federal government between 1900 and 2020. Each column on the graph represents the term of an Australia Federal government (listed beneath) and the height of the column shows the number of coercive laws in existence at the end of each period of government.

Throughout the period 1901-2020, the number of coercive statutory provisions plotted on the graph depicts a 'J-shaped' curve. This curve represents a trend toward penal labour regulation in the early $20^{\text {th }}$ century, followed by the abolition of much of this legislation as a result of struggles between labour and capital in the 1920s and 30s, climaxing in the Great Depression in 1929. There was little such legislation throughout the period of the 'long boom' and the height of union power during the mid- $20^{\text {th }}$ century. The curve trends sharply upwards from the mid-1970s with the first neoliberal industrial reform. The curve accelerates and spikes during the term of the Howard Coalition Government between 1996 and 2007, dipping marginally with the introduction of the Fair Work Act 2009 by the Gillard Labor Government, before increasing and remaining relatively constant under the term of the 
Abbott-Turnbull-Morrison Coalition Governments. Compared over time, the current Morrison Government is presiding over one of the most intensive periods of coercive labour legislation in Australian history, second only to that of the Howard Government.

Significantly, Figure A depicts repeals of coercive labour legislation as well as laws passed. The major repeals occurred first during the term of the radically conservative Bruce-Page Government between 1923 and 1929, when it repealed the health and safety provisions within the Navigation Act 1912 that predominantly affected capital. At the same time, this government enacted some of the most punitive laws against labour in the form of its notorious, Transport Workers Act 1928 (or 'dog-collar act', as it became known by the labour movement (Anderson)) which imposed a punitive licensing regime against wharf labourers by favouring non-union workers. It involved fines for unlicensed workers and significant penalties, including deregistration, for trade unions. Combined with the onset of the Great Depression in 1929, these draconian reforms aroused such antipathy towards the Government and its coercive labour laws that between 1929 and 1931, the Scullin Labor Government was elected on a platform to repeal or amend the Bruce-Page laws. It did so and in the process, repealed nearly every single coercive provision under the Conciliation and Arbitration Act 1904.

A more critical representation of this data is contained in the clustered column graph (Figure $B$ ) below (over page). Figure $B$ adds further crucial detail to explain the number of coercive and punitive laws enacted against either labour, capital or both between 1900 and 2020. Note that this graph does not show repealed laws throughout the period (as depicted in Figure A). Before analysing the meaning of these laws over time, however, it is crucial to narrate a 
chronology explaining the major industrial legislation from each period, corresponding with the columns on both charts.

Figure A - Number of coercive laws passed and repealed, 1901-2020

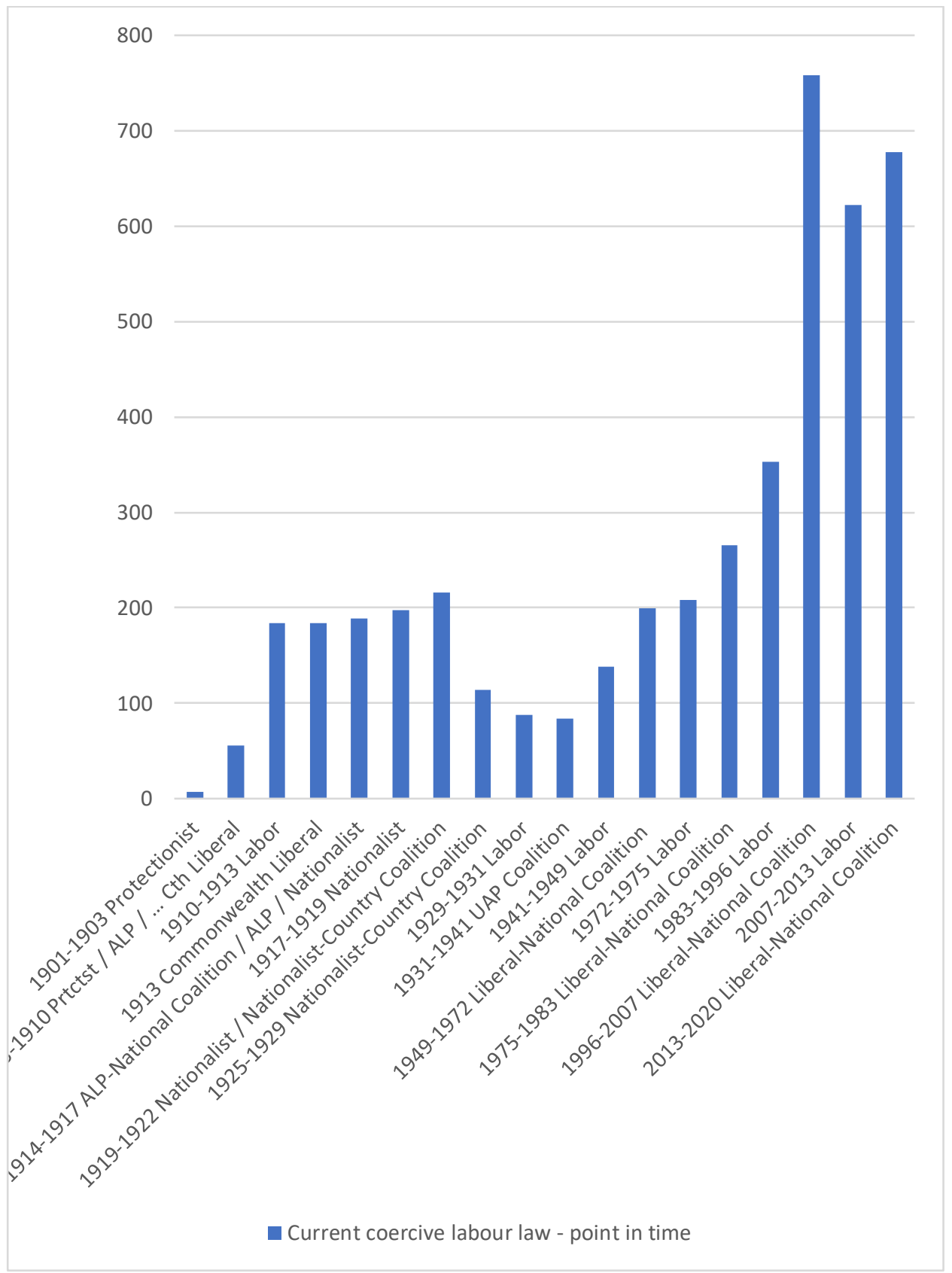


The Conciliation and Arbitration Act 1904 was the response by $19^{\text {th }}$ century liberal reformers to lengthy strikes and industrial turmoil during the 1890s in Australia. Depression had roused employers to cut wages and conditions, precipitating labour strikes and in turn, nation-wide food shortages. In the process, entire trade unions were destroyed and their leaders imprisoned by capital and the judiciary (Macintyre, 1989: 178-179). As one unionist put it, 'the more our liberties were infringed by the State, the more freedom was possessed' (Trenwith quoted in Macintyre, 1985: 47). Accordingly, many within the early Australian labour movement sided with middle-class liberal reformers such as the Protectionist and Labor Party politician, Charles Kingston. His Conciliation and Arbitration Act was designed to achieve industrial harmony by requiring labour and capital to resolve disputes through a system of compulsory arbitration administered by the liberal state (Mitchell, 1989). Rather than subjecting industrial disputation and strikes to common law remedies such as tort law which had crippled the trade union movement in the 1890s - the new system subjected industrial action to a regime of (56) penal sanctions. In return, the labour movement gained a pivotal role in wage-setting and defining terms and conditions of employment across entire industries (Mitchell, 1989).

The period 1910-1913 saw the Fisher Labor Government pass the Navigation Act 1912, largely in response to concerns from the labour movement (backed by a Royal Commission), for the welfare and conditions of seamen, particularly international crews (Kirkby, 2012: 180). Accordingly, the Act imposed extensive penal sanctions (128), predominantly against the owners and managers of shipping companies, in relation to the safety and conditions of their sailors. Save for the Bruce-Page Government's repeal of these provisions (discussed above), successive amendments to the Act after the 1920s saw further penal provisions, 
mainly against capital, inserted into the Act in 1921, 1935, 1953 as well as throughout the 1960s and 70s.

Labour legislation throughout the WWI-era was dominated by coercive laws against unionists and members of the International Workers of the World (IWW) - the organisers of the 1917 general strike. This period also saw the Labor Government of William (Billy) Hughes establish the first coercive special tribunals to discipline militant unions - in this case the Seamen's Union (Bennett, 1994: 23) - through laws similar to today's Australian Building and Construction Commission.

As discussed above, the Bruce-Page Government (1923 to 1929) enacted numerous coercive provisions (33 in all, see Figure B), specifically against the maritime unions. Anti-strike provisions under the Conciliation and Arbitration Act were bolstered while 103 health, safety and worker welfare laws under the Navigation Act were dismantled. In addition, the Commission was empowered to dissolve whole awards to penalise striking trade unions. It was also at this time that anti-strike provisions were inserted into the Commonwealth Crimes Act 1914. In the 1929 election, which saw this Government removed from office, Prime Minister Bruce campaigned on a platform to abolish the entire Conciliation and Arbitration system, proposing its replacement with a master and servant-style common law or courtbased system (Anderson, 1928: 296). The incoming Scullin Labor Government, quickly removed the coercive provisions enacted by its predecessor as well as a raft of others (26 in total)(Robertson, 1974: 254-256). 


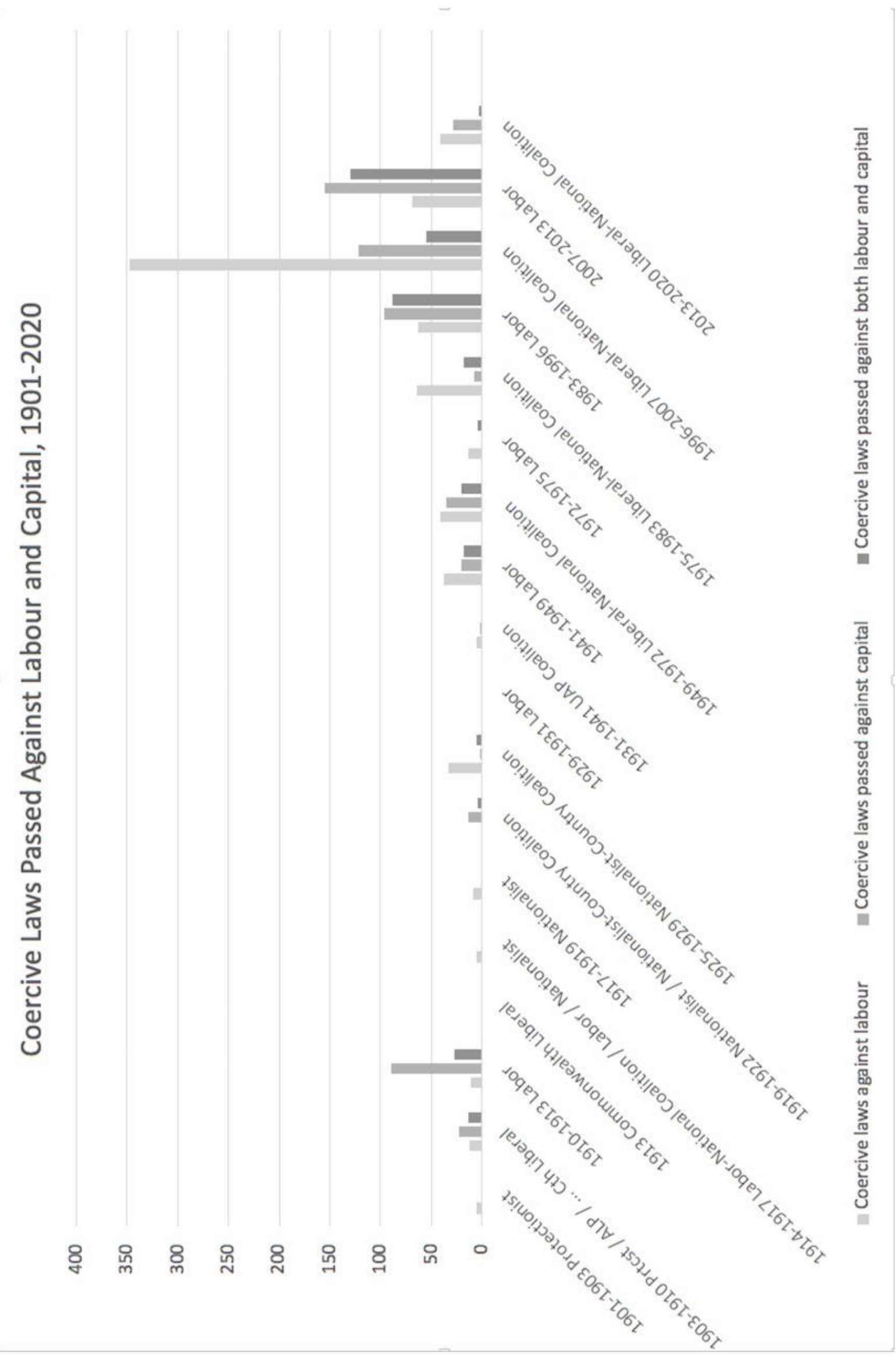


The brief reprieve from coercive labour law during the term of the Labor Government was short lived. The ensuing United Australia Party Government of Joseph Lyons reintroduced a number of coercive provisions into the Conciliation and Arbitration Act along with a broadly drafted provision allowing the Tribunal to make 'any order or provision' in an award (s38(b)). In 1936, a majority of the High Court expanded the definition of this clause to permit the Tribunal to insert 'bans clauses' into awards (allowing an executive tribunal to create its own penal provisions enforceable by a Court) (Seamen's Union of Australasia v Commonwealth Steamship Owners' Association (1936) [1936] HCA 8; 54 CLR 626). ${ }^{\mathrm{v}}$ This juridification of coercive labour law, spanning the 1950s to the 1980s, frustrated trade unions, from time-to-time subjecting them to large fines imposed by the judiciary (Bennett, 1994: 7484).

The wartime Curtin Labor Government, relied upon an extensive number of coercive provisions to increase production and employ women to replace men in many industries. An even greater number of coercive provisions were introduced in the post-war period by the Chifley Government to aid its reconstruction plans by delivering full employment. While most coercive provisions were aimed at capital, the Government enacted 'emergency legislation' containing severe criminal sanctions against striking miners whose communistled union threatened revolution in the Hunter Region of New South Wales. The legislation led to deregistration of the union and, significantly, was repealed as soon as the crisis had abated (Rowse, 2004: 37-38). In a reversal of the 'dog collar acts', Chifley repealed the Bruce-Page Government's Transport Workers Act 1928, enacting the Stevedoring Industry Act 1947, rendering stevedoring licences conditional upon union membership, with penalties for non-union members and employers who hired them. 
The 22-year mid-century span of Coalition Government (from Prime Minister Robert Menzies (1949-1966) to Holt, Gorton and McMahon) occurred at the height of union power within the conciliation and arbitration system and was a time of relative industrial stability. While the longevity of Coalition Government was mostly due to a split in the opposition Labor Party, some have speculated that it was due, in-part, to the outsourcing of coercive industrial disputation by the Menzies Government to the industrial tribunal and courts (Bennett, 1994: 78-84). This juridification involved bolstering 'contempt-of-court' provisions and 'bans' clauses under the Conciliation and Arbitration Act. They were of little effect and were rarely enforced (Creighton, 1991). Nevertheless, only a handful of punitive industrial provisions were legislated throughout this period. Punitive provisions were mostly confined to Menzies' campaign against the maritime unions (Kirkby, 2012: 185-191). On this front, the Government scrapped the recent Chifley Government reforms, reintroducing punitive licensing laws and establishing a special Stevedoring Industry tribunal. It is worth noting that the powers of this special tribunal are nearly identical to those established by the Howard Government and resurrected by the Turnbull Government, against the militant construction union (the CFMMEU) in recent times. The Government also inserted a small number of maritime safety penalty provisions against shipping owners into the Navigation Act, upholding international treaty obligations. The overall lack of punitive laws against unions, despite being outsourced to tribunals and courts during this period, coincided with the high point of union strength and power. Accordingly, where coercive labour law did exist, it did not affect the capacity of unions to act as a key institutional feature of the conciliation and arbitration system. 
The short-lived Whitlam era of progressive Labor Government (1972-1975) saw only minor change to the industrial landscape. Coercive legislation was confined to peripheral regulation of the public service. Dovetailing with the first neoliberal national budget (introduced by the Whitlam Government before being dismissed from office in 1975), as well as a labour market shift toward independent contracting, the ensuing Fraser Coalition Government introduced the first punitive neoliberal reforms to labour law (90 in total, almost as many as the previous Liberal Governments had enacted in 23 years of governance between 1949 and 1972). The Fraser Government created a raft of new offences for ‘industrial action' directed against nonunion labour (independent contractors and non-union members). Perhaps the most wellknown Fraser reforms were anti-strike provisions built into the Whitlam Government's first consumer protection laws - the Trade Practices Act 1974. The amendments protected capital through the circuitous logic of offering consumer protection against the effects of industrial action down the supply chain (ss45D and 45E). The Act prohibited 'sympathy strikes' or 'secondary boycotts' - strikes in support of workers at another enterprise - affording employers the novel remedy of injunctive relief (court orders for an immediate stop to industrial action merely by raising the possibility of 'economic harm' to an employer's business). Penalties for breach of these provisions as well as anti-strike provisions under the Conciliation and Arbitration Act were significantly increased. They included union deregistration. Good 'character' requirements, subject to disqualification, were also imposed on workers and unionists.

Coercive labour law under the ALP Hawke and Keating Governments (1983-1996) was associated with a systemwide shift away from the arbitration system, based on industry-level bargaining, toward a 'corporatist' model of industrial relations, based on enterprise or firmlevel bargaining. Sometimes referred to as 'managed decentralism' (Buchanan and Callus, 
1993: 516), this system replaced the traditional Australian role of unions in industry bargaining with a new role in high-level government decision-making. Industry bargaining devolved to enterprise-level negotiation, which could now completely exclude trade unions. Enforcement of this decentralised system required penal provisions from the Conciliation and Arbitration Act as well as neoliberal coercive laws from the Fraser-era, to be rewritten into a new Industrial Relations Act 1988 - although 'bans' clauses were extinguished, replaced by an array of offences for 'unlawful industrial action'. Also extinguished was the ancient common law and statutory moratorium on industrial action: strikes were limited to circumstances encouraging enterprise bargaining. In a sign of the neoliberal times, unfair dismissal was no longer an offence, instead subject to a statutory compensation scheme. The coercive powers of the Human Rights Commission were enhanced. Reflecting more traditional labourist concerns, so too were health and safety protections for Commonwealth public servants, maritime and transport workers. Perhaps the most coercive laws of the period involved an Act of Parliament in 1986 to deregister the militant - and by this stage, corrupt Builders Labourers Federation (BLF). While not as coercive as neoliberal reform that preceded and succeeded it, an increase in coercive labour law during the Hawke and Keating period (248, with 161 repealed) reflected the expansive breadth of the neoliberal project implemented by this Labor Government.

The period 1996-2007, saw the Howard Coalition Government implement what some commentators have referred to as 'unique levels of state intervention and prescription' in the realm of labour law (Cooper and Ellem, 2008: 532; Hyman, 2001). The general aims of this interventionist neoliberalism were 'to reduce union power and drive individualisation of the employment relationship' (Cooper and Ellem, 2008: 533) by attacking the arbitral model, collective bargaining and trade unions - fundamental to the success of the previous 
conciliation and arbitration system and an industrial relations 'middle-ground' (Cooper and Ellem 2017, 2013). That much of this government's labour legislation - the Workplace Relations Act 1996 and later, Work Choices 2005 - was coercive and directed toward labour, is shown empirically in Figures $A$ and $B$ (above). The apex of the 'J-curve' occurred during this period (525 coercive laws were passed and 161 repealed). Accomplishing this overhaul went beyond rewriting coercive labour legislation, as previous ALP Governments had done. Howard-era strategy demanded dismantling the role of unions in industrial governance, replacing it with state intervention: 'neutral' inspectorates and bureaucratic offices.

The Howard Government rebranded the Keating-era Industrial Relations Act as the Workplace Relations Act. The Act established a labyrinthine set of coercive provisions predominantly targeting organised labour. The Registered Organisations Act, for instance, regulated the minutiae of internal trade union governance. It was supplemented by similarly maze-like procedural regulation of industrial action. In an Australian first, individual employment contracts were enshrined in legislation and designed to exclude union representation. Attached, were a myriad of coercive compliance conditions for employers, as well as unions, to protect individual employees from union 'discrimination'. And, just as the Bruce-Page and Menzies Coalition Governments had sought to break the union movement by targeting the most powerful unions - the maritime unions - the Howard Government deployed a similar strategy. In the same year as Work Choices, the government created the Australian Building and Construction Commission, providing it with punitive powers to enforce new penal provisions, predominantly against the powerful construction industry unions, the CFMEU and Electrical Trade Union (ETU). Such juridification shifted much labour law enforcement away from the tribunal system (established by the Conciliation and Arbitration Act) into federal courts (Dabscheck, 2001). It further entrenched the 
decollectivisation of Australian industrial relations (Coulthard, 1999: 50), resulting in pervasive managerial unilateralism (Deery and Mitchell, 1999: 2; Cooper et al 2009: 340). The resulting backlash by the labour movement, however, fomented a popular perception of 'government overreach' at the 2007 federal election.

Accordingly, the 2007 electoral victory of the Rudd Labor Government owed much to the unpopularity of Work Choices. In replacing Work Choices and the Workplace Relations Act, the Gillard Labor Government enacted the Fair Work Act 2009 which recodified the same major offences from the previous Act. A key difference between the new scheme and the former, however, was the pivotal role played by collective union decision-making in collective bargaining (mainly through the mechanism of 'majority support determinations', required before bargaining (Ellem and Cooper, 2013: 177; Forsyth and Stewart, 2017: 111). Nevertheless, unions still had 'outsider interest group status' in the eyes of Government (Cooper, Ellem and Wright, 2015: 239-240) and bargaining could continue to occur without them. A primary role of the Act was to extend the 'general protections' for individual workers from the previous Act, to which were attached penalty provisions, thereby continuing the individual rights approach to labour law taken by the Howard Government (Forsyth and Stewart, 2017: 116-119). As the architect of this scheme, Andrew Stewart, has since commented, such a move meant that the reforms satisfied the neoliberal Productivity Commission, whose opinion appears to have been the benchmark for industrial governance since its establishment by the Howard Government in 1998 (Forsyth and Stewart, 2017: 112116). The Gillard Government also repealed lengthy tracts of coercive legislation relating to the Australian Building and Construction Commission (also changing its name) but added penal sanctions to trade union governance legislation. In addition, it implemented a national code of work health and safety, along with two specialised schemes for marine and road 
transport safety, each containing extensive penal provisions against capital. Given the large volume of coercive provisions contained in the health and safety legislation, and notwithstanding the piecemeal reform brought about by the Fair Work Act, the overall number of coercive provisions was reduced (490 coercive provisions were repealed from the Workplace Relations Act, replaced by only 354 such provisions in the Fair Work Act). This is represented in Figure A (above) by a dip in the overall volume of coercive regulation. There was also a significant decline in coercive regulation enacted against labour (see Figure B).

The current period of Coalition Government (2013 - 2020) has been marked by an uptick in the number of coercive labour provisions (73), with the current Morrison Government presiding over a period containing the second highest number of punitive labour laws in Australian history (Figure A). This is so, even after the Government abolished one of the transport safety schemes, containing a raft of punitive provisions against capital. Following a Royal Commission into Trade Union Governance and Corruption, initiated by the Abbott Government in 2013, the conservative former High Court Justice Dyson Heydon, recommended a raft of new penal provisions in respect to trade union governance as well as the reinstatement of a range of coercive provisions to the Building and Construction tribunal. While two tranches of this legislation have passed through the Parliament, a third and more extreme tranche of criminal provisions in respect to trade union governance failed to pass the senate on three occasions - partially blocked on the final occasion by far-right Senator Pauline Hanson (Schofield-Georgeson and Rawling, 2020: 433). Demonstrating the failure of the individual rights approach to labour law, much of the Coalition Government's punitive legislation has been directed against capital, following public outrage over a number of incidents involving the gross exploitation of vulnerable workers. As discussed below, where unions have been forced out of the industrial arena, punitive legislation has been required to 
take their place. (Schofield-Georgeson and Rawling, 2020: 427). While not counted in this study, industrial manslaughter, wage theft, labour hire and anti-slavery laws are expanding across state and territory jurisdictions.

\section{Discussion}

The trend away from democratic industrial law, toward coercive labour law, was precipitated by the Fraser Government, aided by the Hawke and Keating Governments. It spiked under the Howard Government and is continuing under the present Government. The ' $\mathrm{J}$ '-shaped curve described in this study shows a quantitative recent growth in punitive labour legislation, particularly against labour. Despite being given labels such as 'civil penalty' and 'civil remedy' provisions, as noted above, even the High Court has described such laws as having a coercive quality. While such a trend clearly targets labour, such laws might also be taken to be of concern to capital. In this respect, the proliferation of coercive labour law since the 1990s raises a serious question about the democratic nature of regulatory governance in the industrial sphere, compared to other forms of industrial governance - primarily conciliation and arbitration - that existed throughout most of the $20^{\text {th }}$ century.

The recent surge in coercive and individualised law reinforces neoliberal employment relations. It is a form of labour law designed to protect workers individually in a juridical forum, rather than asserting labour rights through collective negotiation between groups of workers and employers and in fact inhibiting the means of collective action in the process. As Friedrich Hayek saw it nearly 60 years ago, employment protections which defend the individual freedoms of all workers while reducing the power of organised labour is neoliberal strategy (Smith, 2015: 351; Hayek, 1960: 267, 269, 272, 273). For neoliberals, an intended 
consequence of upholding labour 'standards' in this way is a concomitant decline in the bargaining power of collective labour which, in turn, translates into a material windfall for capital (Whyte, 2019: 1-34, 196-197, 242). It is no accident that the decline in collective bargaining, observed since the introduction of enterprise bargaining by the Hawke and Keating Governments and the first widespread implementation of coercive labour law, correlates markedly with a decline in union density (Sheldon, 1998), real wages (ABS, June 2020) and an increase in non-unionised precarious work (casualisation, independent contracting and labour hire) (Rawling, 2015). Meanwhile, (in the pre-pandemic period) company profits and productivity have boomed while and disparities in wealth have been ever-increasing (Austin, 2019). As commentators, Panitch and Swartz (2003: 6) have observed in relation to a similarly coercive trend in Canadian labour law, 'the era we have entered marks a ... more open reliance of state and capital on coercion - on force and on fear - to secure (the) subordination' of labour. Clearly, coercive and individualised neoliberal labour law has not delivered on its promise of individual freedom and its results for industrial democracy have been to fragment and reify a wider social democratic project (Adams, 1991).

The key finding of this research paper has been to historicise the present neoliberal industrial framework, characterised by an increase in individual and coercive labour law. In so doing, the conciliation and arbitration system, particularly that established between the 1940s and 1970s, emerges as a uniquely democratic time for collective Australian labour relations. It must be acknowledged, of course, that this was a time in which many other social injustices were apparent, particularly in respect to the social composition of the labour force: women were, to a large degree, excluded from workplaces by discriminatory labour practices common to both labour and capital; the White Australia Policy (excluding non-European migrants from entering the country and thereby, Australian employment) was in full-swing; 
and Aboriginal workers, particularly in the pastoral sector, were subject to gross exploitation and sometimes slavery. Despite the historical legacy of these exclusionary policies (which endures today), there is much to be learnt from industrial policy throughout this period.

This was a time at which social relations between organised (male) labour and capital and the resulting industrial legislation passed over the course of this period, benefited from a lack of coercive and punitive labour law. Unions grew in strength, assisting with the enforcement of labour law - both individual and collective. The 'partnership' stance taken toward unions, enshrined within the conciliation and arbitration system, meant that labour law was collective, solidaristic and negotiated between strong unions across entire sectors and industries often with groups of employers in a tribunal setting. Between the 1940s and mid1970s, this legal environment fostered the longest and most sustained rise in real (male) wages ever recorded (Hancock and Richardson, 2004: 140-141). Meanwhile, Industrial relations were rarely individual or focussed on the employment 'rights' of individual workers as decided by a judge. Punitive sanctions for labour and capital were scarce in the legislation (and even more rarely, enforced (Stewart et al, 2016: 921). Such was the strength of this collective process that a federal labour inspectorate, designed to police individual breaches of labour law, was not formally established until 1928, with the first inspector appointed in 1934! (Goodwin and Maconochie, 2011).

As historical analysis of the foundations of the conciliation and arbitration system has shown, this system was the product of 'neither capital, nor labour' (Macintyre, 1989: 182). As the system progressed throughout the twentieth century its functions became intertwined with a dominant and accepted mode of Keynesian production (a class compromise between labour 
and capital). By the 1930s, the conciliation and arbitration system became both formative of and formed by a political acceptance of 'associative democracy' (Cohen and Rogers, 1995: 44) - a concept referred to at the outset of this paper.

In 1995, Joshua Cohen and Joel Rogers, coined the term, 'associative democracy' to assist in designing what they say as new and wider socially emancipatory possibilities for the stagnant state of neoliberal politics within liberal democracies. 'Associative democracy' is the idea that by representing different social groups, associations are best suited to addressing: (i) inequalities in material resources by organising marginalised people for political purposes; (ii) educating citizens; (iii) solving informational problems for policymakers; and (iv) becoming a pivotal force in various forms of collective problem solving (Cohen and Rogers, 1995: 42-44; Wright, 2010: 180).

Among the neoliberal problems that they sought to address was the 're-regulation' of labour law, already enacted at that time by Reagan in the US and Thatcher in the UK and followed shortly after in Australia under the Howard Government. As the late US sociologist and social theorist, Erik Olin Wright, put it,

'centralised (neoliberal) administrations are good at imposing uniform rules over homogeneous contexts, but have great difficulty in creating effective rules to deal with highly heterogeneous contexts. When they try to do so they typically produce heavy-handed regulations that are ineffective and often damaging. This is a chronic problem, for example, in relation to ... workplaces (that) are so diverse and complex that one-size fits all regulations are rarely satisfactory' (Wright, 2010: 181). 
In a contemporary Australian industrial context, heavy-handed uniform rules have replaced a system that once provided for precisely the kind of 'heterogeneous' regulatory nuance necessary in complex workplace contexts. The former system was one overseen and enforced by unions with knowledge of and expertise in their discrete industries and areas of sectoral representation, as partners with the state. The continual locking-out of unions from this state process, particularly through coercive legislation since the 1990s, has in turn created a regulatory gap, now filled by a coercive and (as some have argued (Clibborn, 2020)), ineffective regulatory regime.

But rather than turn to further 'deregulation' or 'reregulation' to respond to the issue, Cohen and Rogers looked to, associative democracy. 'Associative governance', suggest Cohen and Rogers,

'can provide a welcome alternative or complement to public regulatory efforts because of the distinctive capacity of association to gather local information, monitor behaviour and promote cooperation among private actors. In such cases, the associative strategy recommends attending to the possibility of enlisting them explicitly in the performance of public tasks' (Cohen and Rogers, 45).

In an industrial context, such governance is neither coercive nor punitive (with unequal consequences), but rather cooperative and democratic (with comparatively more egalitarian consequences).

While associative democracy was a new concept for US commentators in the mid-1990s, the mid-century Australian conciliation and arbitration system, is an exemplar of this concept in action. By giving trade unions a stake in the making and enforcement of labour law, the 
conciliation and arbitration system enabled a 'flow' of gains from strong, unionised sectors of the workforce to weaker and more vulnerable sectors. In this respect, such a system has the inbuilt potential to regulate and redress problems for vulnerable workers, exposed to underpayment and gross exploitation, without enacting further coercive and punitive regulation. As Mitchell found in 1979, following the peak of the conciliation and arbitration system, coercive legislation enacted against both labour and capital was mostly unnecessary (p. 462) and previously, there had been little of it on the statute books. Meanwhile, Cooney, Howe and Murray (2006) reached similar conclusions regarding the efficacy and democratic social practice embodied by the conciliation and arbitration system (p. 215).

There has, nevertheless, always been a social democratic need for public law to regulate discrimination, health and safety, compensation for workplace injury, freedom of association and prohibitions on child labour. Indeed, such issues are publicly uncontroversial (Cooney, Howe and Murray (2006: 215)) and historically, as this study has found, governed by a handful of relatively straightforward penal provisions correlating with periods of social democratic governance. These laws may be thought of having a place within a system of 'associative governance', rather than 'coercive labour law'. Contemporary industrial manslaughter and modern slavery laws - while products of the existing neoliberal regulatory system that have sidelined trade union and tribunal enforcement - might also be viewed in a similar way.

Incidentally, by being built into the framework of associative regulation and its enforcement through the conciliation and arbitration system, trade unions were permitted to prove their worth and union density remained high. This, in turn, enhanced their resources and power to 
enforce labour law. Such was their influence in the early conciliation and arbitration period that broader market problems associated with the destruction of industries through 'fissured workplaces' and counter-posing issues of monopoly capitalism, were subject to serious, union-sponsored regulation through the Australian Industries Preservation Act 1906, ss4-9.

Given the anti-democratic industrial and social consequences of the current system, based as it is in punitive law, there is much to be adapted from those more civil(ised) aspects of a previous industrial system that yielded more democratic results for stakeholders. As Australian industrial commentators like the late Joe Isaac have recently claimed, the reestablishment of such sectoral or pattern bargaining, for instance, in a is something to be welcomed and fostered by the State, rather than shunned and regulated out of existence, on trend with the past few decades of Australian industrial legislation (2018: 183-185).

\section{Conclusion}

Throughout the $20^{\text {th }}$ century, coercive legislation was mostly absent from the province of Australian labour law. When passed against capital, such legislation was usually designed to ensure health and safety or to provide reciprocal obligations in respect to labour. When passed against labour, it surfaced at times of crisis or in the name of the odd crusade by a conservative Prime Minister against a strong union movement. This paper has shown by way of historical comparison that while this trend commenced in the 1970s, there has been an acceleration of such laws on the statute books since the 1990s. While many such laws have been directed toward policing and dismantling trade unions, others have been directed at capital, to enforce individual labour rights. In this respect, they have served a related purpose in individualising or juridifying employment relations which has the practical effect of 
excluding unions from what have become increasingly atomised, rather than collective, industrial relations.

The shift from sectoral bargaining moderated by a civil model of industrial relations, to an enterprise model based on mostly individual enforcement through coercive law, correlates with a raft of new and emerging industrial problems. Not least of which is a fundamental lack of industrial democracy in the way in which law is imposed upon aggrieved or disputing industrial parties. More specific data regarding the empirical outcomes and effects of this new punitive industrial arena might be explored in a separate project - perhaps comparing enforcement of the legislation surveyed here over time. As it stands, however, the previous system of relatively non-coercive industrial law offers a credible alternative to the current regime. Integral to this system was a notion of associational democracy which involved the subjects of industrial law - labour and capital - together with the state in crafting law and working conditions for themselves. In 2018, both the Australian Council for Trade Unions (ACTU) along with the Organisation for Economic and Co-Operative Development (OECD) lent policy support to industrial commentator Joe Isaac's (2018) call for a return to pattern and sectoral bargaining (Workplace Express, 2019). Such a position may yet spell the decline of coercive and punitive labour law and the reinvigoration of associative or industrial democracy. In the meantime, however, coercive labour law remains the 'new normal' for Australian neoliberal labour relations. 


\section{References:}

Adams R (1993) Regulating Unions and Collective Bargaining: A Global, Historical Analysis of Determinants and Consequences. Comparative Labour Law Journal 14: 272-301.

Adams R and Markey R (1997) How the State Influences Trade Union Growth: A Comparative Analysis of Developments in Europe, North America and Australasia. The International Journal of Comparative Labour Law and Industrial Relations 13(4): 285-303.

Anderson G (1928) The Commonwealth Conciliation and Arbitration Act 1928. The Economic Record 4: 279-301.

Austin A (2019) Corporate profits and government spending boom while wages and economy languish. Michael West Independent Media, 5 September:

https://www.michaelwest.com.au/corporate-profits-and-government-spending-boom-whilewages-and-economy-languish/

Australian Bureau of Statistics (2020) 6345.0 - Wage Price Index, Australia, June: https://www.abs.gov.au/AUSSTATS/abs@.nsf/Latestproducts/6345.0Media\%20Release1Jun $\% 202020$ ?opendocument $\&$ tabname $=$ Summary \&prodno $=6345.0 \&$ issue $=$ Jun $\% 202020 \&$ num $=$ \&view $=$

Ayres I and Braithwaite J (1992) Responsive Regulation: Transcending the Deregulation Debate, Oxford University Press.

Baldwin R (1997) Regulation after 'Command and Control' in Hawkins K (ed), The Human Face of Law: Essays in Honour of Donald Harris, Oxford: Clarendon Press, 65-84.

Baldwin R and Black J (2008) Really Responsive Regulation. Modern Law Review, 71(1): 59-94.

Bennett L (1994) Making Labour Law in Australia: Industrial Relations, Politics and Law. Annandale: The Federation Press.

Bryman A (2016) Social Research Methods. Oxford: Oxford University Press.

Buchanan J and Callus R (1993) Efficiency and Equity at Work: The need for labour market reform in Australia, 35(4): 515-537.

Clibborn S (2020) Australian industrial relations in 2019: The year wage theft went mainstream. Journal of Industrial Relations, 62(3): 331-340.

Cohen J and Rogers J (1995) Associations and Democracy, New York:Verso.

Collins H (2010) Employment Law, $2^{\text {nd }}$ Edition, Oxford: Oxford University Press.

Cooney S, Howe J and Murray J (2006) Time and Money under Workchoices: 
Understanding the New Workplace Relations Act as a Scheme of Regulation. University of New South Wales Law Review 29(1): 215-242.

Cooper R and Ellem B (2008) The Neoliberal State, Trade Unions and Collective Bargaining in Australia. British Journal of Industrial Relations 46(3): 532-554.

Cooper R and Ellem B (2013) The State against Unions: Australia's Neo-liberalism, 19962007. In: Gregor G and Dundon T (eds) Global Anti-Unionism, London: Palgrave MacMillan, pp. 263-284.

Cooper R and Ellem B (2017) Cold Climate: Australian Unions, Policy, and The State. Comparative Labour Law and Policy Journal 38: 415-436.

Cooper R et al (2009) Anti-Unionism, Employer Strategy, and the Australian State, 19962005. Labor Studies Journal 34(3): 339-362.

Cooper R, Ellem B and Wright CF (2015) Policy and the Labour Movement. In Head B and Crowley K (eds) Policy Analysis in Australia. Bristol: Policy Press, pp. 231-244.

Coulthard A (1999) The Decollectivisation of Australian Industrial Relations: Trade Union Exclusion Under the Workplace Relations Act 1996 (Cth). In Deery S and Mitchell R (eds), Employment Relations. Annandale: The Federation Press, pp. 48-68.

Creighton B (1991) Enforcement in the Australian Industrial Relations System: An Australian paradox. Australian Journal of Labour Law 4: 197.

Dabscheck B (2001) 'A felt need for increased efficiency': industrial relations at the end of the millennium. Asia-Pacific Journal of Human Resources 39(2): 4-30.

Deery S and Mitchell R (1999) The Emergence of Individualisation and Union Exclusion as an Employment Relations Strategy. In Deery S and Richard M (eds), Employment Relations. Annandale: The Federation Press, pp. 1-16.

Forsyth A and Stewart A (2016) Swimming Against the Tide: New Challenges for Unions under Australian Labor Law. Comparative Labour Law and Policy Journal 38: 99-122.

Gilfillan G and McGann C (2018) Trends in union membership in Australia. Parliament of Australia:

https://www.aph.gov.au/About_Parliament/Parliamentary_Departments/Parliamentary_Librar y/pubs/rp/rp1819/UnionMembership.

Hancock K and Richardson S (2004) Economic and Social Effects. In Isaac J and Macintyre $\mathrm{S}$ (eds), The New Province of Law \& Order. Cambridge: Cambridge University Press, pp. 139-206. 
Hardy T and Howe J (2009) Partners in Enforcement? The New Balance Between Government and Trade Union Enforcement of Employment Standards in Australia. 22 Australian Journal of Labour Law 22(3): 306-336.

Harley B (2004) Managing Industrial Conflict. In Isaac J and Macintyre S (eds), The New Province of Law \& Order. Cambridge: Cambridge University Press, pp. 316-344.

Hayek FA (1960) The Constitution of Liberty, London: Routledge.

Howe J, Hardy T and Cooney S (2012) The Transformation of Enforcement of Minimum Employment Standards in Australia, Centre for Employment and Labour Relations Law, Melbourne.

Hyman R (2001) The Europeanisation - or the erosion - of industrial relations. Industrial Relations Journal 32(4): 280-94.

Isaac J (2018) Why Are Australian Wages Lagging and What Can Be Done About It?. The Australian Economic Review 51(2): 175-190.

Kirkby D (2012) 'The sailor is a human being': Labour Market Regulation and the Australian Navigation Act 1912. In Kirkby D (ed) Past Law, Present History. Canberra: ANU Press, pp. 177-192.

Lacey N (2013) The Rule of Law and the Political Economy of Criminalisation: An agenda for research. Punishment \& Society 15(4): 349-366.

Macintyre S (1985) Winners and Losers: The Pursuit of Social Justice in Australian History. North Sydney: Allen \& Unwin.

Macintyre S (1989) Neither capital nor labour: the politics of the establishment of arbitration. In Mitchell R and Macintyre S (eds) Foundations of Arbitration: The Origins and Affects of State Compulsory Arbitration, 1890-1914. Melbourne: Oxford University Press, pp. 178-200.

Macintyre S and Isaac J (2004) The New Province of Law and Order: 100 years of Australian Industrial Conciliation and Arbitration, Melbourne: Cambridge University Press.

Maconachie G and Goodwin M (2011) Minimum Labour Standards Enforcement in Australia: Caught in the Crossfire?. Economic \& Labour Relations Review 22: 55-88.

Merritt AS (1981) The Development and Application of Masters and Servants Legislation in New South Wales - 1845 to 1930. PhD Thesis, Australian National University.

Mitchell R (1989) State Systems of Conciliation and Arbitration: The origins of the Australasian model. In Mitchell R and Macintyre S (eds) Foundations of Arbitration: The Origins and Affects of State Compulsory Arbitration, 1890-1914. Melbourne: Oxford University Press, pp. 74-103.

Mitchell R (1979) Industrial Relations Under a Conservative Government: The Coalition's Labour Law Programme 1975 to 1978. Journal of Industrial Relations 21(4): 435-465. 
Mitchell R (1980) Industrial Relations Under A Conservative Government: A Reply. Journal of Industrial Relations 22(3): 348-358.

Mitchell W and Fazi T (2017) Reclaiming the State: A Progressive Vision of Sovereignty for a Post-Neoliberal World, London, Pluto Press.

Owens R, Riley J and Murray J (2007) The Law of Work, Second Edition. Melbourne: Oxford University Press, Melbourne.

Panitch L and Swartz D (2003) From Consent to Coercion: The assault on trade union freedoms, Third Edition. Ontario: Garamond Press.

Peetz, D (1998) Unions in a Contrary World: The future of the Australian trade union movement, Melbourne: Cambridge University Press.

Quinlan M (1989) 'Pre-arbitral' labour legislation in Australia and its implications for the introduction of compulsory arbitration. In Mitchell R and Macintyre S (eds) Foundations of Arbitration: The Origins and Affects of State Compulsory Arbitration, 1890-1914.

Melbourne: Oxford University Press, pp. 25-49

Rawling M (2015) Regulating Precarious Work in Australia: A Preliminary Assessment. Alternative Law Journal 40: 252-256.

Rawling M and Schofield-Georgeson E (2018) Industrial Legislation in Australia, 2017. Journal of Industrial Relations 60(3): 378-396;

- (2019) Industrial Legislation in Australia, 2018. Journal of Industrial Relations 61(3): 402-420;

Robertson J (1974) J.H. Scullin: A Political Biography, Perth: University of Western Australia Press.

Rowse T (2004) Elusive Middle Ground: A Political History. In Isaac J and Macintyre S (eds) The New Province for Law \& Order. Cambridge: Cambridge University Press, pp. 1754.

Schofield-Georgeson E and Rawling M (2020) Industrial Legislation in Australia, 2019. Journal of Industrial Relations 62(3): 425-445.

Sheldon P (1998) Arbitration and union growth: building and construction unions in NSW, 1900-1912. Journal of Industrial Relations 35(3): 379-97.

Smith P (2015) Labour under the law: a new law of combination, and master and servant, in $21^{\text {st }}$-century Britain?. Industrial Relations Journal 46(5): 345-364. 
Stewart A et al (2016) Creighton \& Stewart's Labour Law, $6^{\text {th }}$ Edition. Annandale: The Federation Press.

The Fair Work Ombudsman and Registered Organisations Commission Entity (2019) Annual Report 2018-19.

Tombs S and Whyte D (2007) Safety Crimes. Devon: Willan Publishing.

Whyte J (2019) The Morals of the Market: Human Rights and the Rise of Neoliberalism. London: Verso.

Workplace Express (2015) Union density drop accelerating, as membership decline returns: Peetz, 22 December:

Workplace Express (2018) Industry-wide bargaining a cure for wage stagnation: OECD, 6 July.

Wright EO (2010) Envisioning Real Utopias (New York: Verso).

*The author thanks Dr Maree Murray for her research assistance and Dr Michael Rawling for his collaboration on similar projects. 


\footnotetext{
'See p. 4 for a comprehensive definition of the phrases 'penal, punitive and coercive labour laws'.

ii Federal penalty units are subject to annual increase as prescribed by the Attorney-General, pursuant to the Crimes Act 1914 (Cth), s 4AA. They are currently valued at $\$ 222$ each (Notice of Indexation of the Federal Penalty Unit Amount, Attorney-General, 14 May 2020).

iii Note: Conversely, it was not until the High Court's decision in the Builders Labourers' Case (1914) $(R v$. Commonwealth Court of Conciliation and Arbitration; ex p. G. P. Jones (1914) 18 CLR 224; $R$ v. President of the Commonwealth Court of Conciliation and Arbitration; ex p. William Holyman \& Sons Ltd (1914) 18 CLR 273) that the federal industrial jurisdiction could be used on a mass scale.

iv Around 1.5 million Australian workers are members of national trade unions (Gilfillan and McGann, 2018). Meanwhile, federal registered organisations have around '2 million members' (ROC, 2019: 29).

${ }^{v}$ Note: Labor appointed judges, Evatt and McTiernan JJ dissented. As a punitive legislative device, bans clauses appear to contradict the most hallowed of the High Court's own doctrine in the form of the separation of powers, established by the Constitution (Chapters I, II and III) and in the Wheat Case (1915) HCA 17, (1915) 20 CLR 54, before it became a pillar of Australian constitutionalism and the Court's own judicial power in the Boilermakers' Case (1956) HCA 10, (1956) 94 CLR 254.
} 